\title{
ACQUISITION OF A NULL SUBJECT LANGUAGE
}

\begin{abstract}
Aslı Altan
Abstract

This study analyzes the use of pro-drop in speech among children between the ages 2;0- 4;8 acquiring Turkish as a native language. The data analyzed is part of the CHILDES data base and includes cross-sectional language data from a total of 48 children. The data was categorized according to the type of verb (verbal, nonverbal, existential or imperative) and the age of the child. Those cases where the child omitted the pronoun where it was not recoverable from the context are highlighted. The analysis of the data demonstrates that children from all age groups omit the subject pronouns, especially in verbal sentences. The data from children in the smallest age group demonstrates that they tend to overgeneralize the pro-drop rule to cause ambiguity in some cases. The rate of pro-drop decreases with age and children tend to use it more correctly.
\end{abstract}

Anahtar kelimeler: Language acquisition, native language acquisition, pro-drop. 


\section{BİR ADIL DÜŞÜRME DİLININ EDİNIMİ}

$\ddot{O} z$

Bu çalışmada Türkçe'yi anadil olarak edinmekte olan 2;0- 4;8 yaşs aralığındaki çocukların adıl düşürme özelliğini konuşmalarında kullanımları araştırılmıştır. Çalışmada kullanılan veriler CHILDES veritabanından (Mac Whinney, 1995) elde edilmiş olup kesitsel yöntemlerle 4 ay aralıklara toplam 48 çocuğun konuşmalarını içeren verilerdir. Veriler yaş gruplarına ve adılların kullanıldiğı yüklemin çeşidine göre sınıflandırılmış (eylem, yüklem, var/yok tümcesi, emir kipi) ve incelenmiştir. Bağlama uygun olmayacak şekilde adıl düşürüldüğü durumlar belirlenmiştir. Verilerin incelenmesi sonucunda tüm yaş gruplarındaki çocukların Türkçenin adıl düşürme özelliğini kullandıkları, özellikle de eylem içeren tümce yapılarında adıl düşürmeyi tercih ettikleri gözlemlenmiştir. Küçük yaş gruplarındaki çocukların adıl düşürme özelliğini fazla genellemeleriyle iki anlamlılık ve anlam karışıklığına yol açtığ gözlemlenmiştir. Çocukların yaşlarının büyümesiyle adıl düşürme oranının azalması ve kullanımının anlam karmaşası içermeyerek doğru kullanım olduğu verilerden açıkca görülmektedir.

Anahtar kelimeler: Dil edinimi, anadil edinimi, adıl düşürme. 


\section{Introduction}

This paper analyzes the acquisition of the null-subject property of Turkish. My aim is to provide a review of different approaches to the pro-drop parameter in Turkish, to state the problems in literature and to offer a brief summary. Then I will present the data and subsequently analysis of the data with examples. The final sections include the examples from data, discussion of data and conclusions.

The property of begin pro-drop is defined as the deletion of the overt pronoun in a sentence in cases when the pronoun may be recovered from the pragmatics and the context of the sentence or from the person information on the verb, as can be observed from example (1):

CHI: git-mi-yor-um (Vahide, 2;0)

go- NEG-PRG- 1SG

'I am not going'

Subject deletion is a pervasive and extensively studied property of child language. The main question in this study is whether children acquiring Turkish know the status of subjects in their language. Since Turkish is a morphologically rich language, with verbs agreeing with the subject in person and number, the subject position of a sentence or a noun phrase need not be filled overtly with a phonologically realized noun phrase (Kornfilt, 1984; Özsoy, 1987).

This study attempts to formulate the cases where children drop the pronoun in their utterances. The effect of the type of predicate and the ambiguity caused by lack of the pronoun in cases where the pronoun is deleted in children's speech is examined. Moreover, those cases in which the pronoun is retained are analyzed in detail.

\section{Studies in other languages}

Studies of children's early utterances indicate that subject-less sentences are found both in languages that allow null subjects, such as Italian (Hyams, 1986) and American Sign Language (Lillo-Martin, 1986\&1991), and those that do not, such as French (Pierce, 1987; Weissenborn, 1991). Furthermore, studies of early German, which allows a restricted set of subjects to be null, reveal that children learning German use subject-less sentences beyond those allowed by the adult grammar (Clahsen, 1991; Weissenborn, 1991). Thus, in all of these studies it has been found that at an early age children use subjectless sentences. 
Chomsky (1981) claims that the null-subject parameter is a parameter that children are born with. It has been claimed for pro-drop languages that it is not only grammatical but also conventional for speakers of such a language to drop subjects. Chomsky (1981) proposes that the pro-drop parameter also includes the Avoid Pronoun Principles which forces speakers to omit pronominal subjects wherever possible. Following Chomsky's claim, Hyams (1996) suggests that children begin their language acquisition with a pro-drop language with optional subjects and then they set their parameters in accordance with the language they experience. This restructuring of the Null Subject Parameter takes place around 26 to 28 months. Greenfield and Smith (1976) propose that children acquiring English between 1;10 and $2 ; 3$ are inconsistent in their use of subjects. Some researchers (Hyams, 1986\&1992; Hyams \& Wexler, 1993; Lillo-Martin, 1994) have considered children's inconsistent usage of subjects as a reflection of a lack of knowledge or a competence deficit. Gerken (1991) provided a prosodic explanation in that children tend to omit unstressed syllables in sentence initial position.

Valian (1991, 1996), Valian\& Eisenberg (1996) and Valian et al.(1996) worked extensively on pro-drop in English and in comparative studies (between English and other languages). In Valian (1991), she compared cross-sectional speech of 21 English-speaking children (between ages $1 ; 10$ to $2 ; 2$ ) with the longitudinal speech of 6 Italian children. In Valian\& Eisenberg (1996), it is suggested that Portuguese (also a null-subject language) children use sentential subjects $28 \%$ of the time. Valian et al.(1996) experimented with 19 American children between 1;10 and 2;8 and concluded that children's failute to include subjects was due to processing limitations rather than a grammar that allows null-subjects. Children imitated pronominal subjects less often than lexical subjects. Valian reached the conclusion that American children understand that English requires subjects before MLU 2.0.

Studies on Chinese (Wang, Lillo-Martin, Best \& Levitt, 1996), Japanese (Mazuka, Lust, Wakayama \& Snyder, 1986) and Korean (Kim, 1996) suggest that these children also produce subjects less than their American peers. Grinstead (2004) found that children speaking Spanish and Catalan use subject with non-verbal predicates. Blom \& Geert (2004) argue that children first go through a stage where they overdrop subjects in finite sentences. They claim that knowledge of verbal inflection is a prerequisite for the acquisition of rule-governed subject use.

There are many reasons provided for the deletion of subjects, such a processing load, syntactic competence, characteristics of the input, ignorance of the exact acceptability conditions for subject omission and prosodic effects Valian (1991). Valian notes that children omit subjects when sentence complexity puts too great a 
burden on the production system. On a pragmatic account, Bates (1976) proposes that children have limited production abilities and omit the least communicatively informative elements: because subjects contain given information, they are frequently omitted. Bloom (1990) suggests that children expand sentences rightward, at the expense of leftward elements. According to Hyams (1992), children reset their pro-drop parameter upon evidence from the presence of expletive subjects in English. Children begin using expletive subjects at the same time they use sentential subjects consistently.

What these studies on null subject and non-null subject languages demonstrate is that children's speech reflects the characteristics of their target language even at the outset of production Valian (1991).

\subsection{Studies in Turkish}

There have been various studies on the pro-drop property of Turkish and it remains a matter of dispute whether Turkish is a pro-drop language or not (Öztürk, 1999).

Slobin (1982) points out that rich inflectional paradigms are acquired earlier than poor inflectional paradigms. Zimmer (1984) analyzed adult conversations and categorized the cases where the subject is used post-verbally in Turkish and identified the use of post-verbal subjects as either carriers of 'cooperative conversational sentence information' or emphasis without contrast (Zimmer ,1984: 200).

Enç (1985) and Erguvanl1-Taylan (1986) claim that the use of subject pronouns is conditioned by pragmatic factors, such as topic shift. Erguvanl1- Taylan (1986) states that in certain cases depending on the discourse, where the subject has a topic changing function the subject pronoun is obligatory. Enç (1985) suggests that sentences with pronominal subjects are more marked than their counterparts with null subjects, since they convey extra pragmatic information. She also claims that only sentences that signal the introduction of a new topic have subject pronouns.

Öztürk (2001) proposes that the overt subject pronouns are topic pronouns. Öztürk (2001: 258) argues that overt subject pronouns in Turkish are base-generated in SpecTopP and reveal agreement with the agreement morphology, which is the VPinternal subject in Turkish, eliminating the AgrP from the Infl domain and leading to a non-pro-drop analysis of Turkish. Göksel and Kerslake (2005: 273) propose that the third person pronouns $o$ (he/she/it) and onlar (they) do not occur nearly as often as other person pronouns. The reason provided is that the personal pronoun will often not provide sufficient identification and a more explicit NP is preferred. $O$ (he/she/it) and onlar (they) can be used only where an unambiguously identifiable referent is available. 
The only study that investigates the acquisition of null-subject property is by Slobin \& Talay (1984) who worked on the pragmatic use of subject pronouns in Turkish. They only focused on those sentences where the child uses an overt subject. They claim that subject marking in Turkish must attend to the fact that the speaker has three options: to encode the subject by verbal infection alone or by an explicit pre/post verbal noun or a pronoun. All these options have different pragmatic functions. Slobin \& Talay examined hour-long speech transcripts from nine children, spaced in age at four-month intervals between the ages of 2;0 (24 months) to $4 ; 8$ (56 months). They analyzed all child utterances with subject expressed by pronoun and verb inflection alone. They propose that by $2 ; 0$ subject agreement is correctly marked on verbs across a range of tenses, and all three pronominal options are exercised: null, preposed and postposed pronouns. Furthermore, they found out that these perform different functions. They categorized postverbal subject pronouns as conveying assertive mode, expressing insistence, emphasis or challenger, with focus on the verb or object. They conclude that both semantic (verb-inflectional) and pragmatic (pronominal options) marking of sentence subject is well established at an early age. They show that children use null subject option available to them in the language for expressing different language functions. They analyzed these different discourse functions in detail by dividing them into three: response to question or imperative, declaration of intention or need, offering of information. Their study suggest that the null subject option is related to certain discourse functions.

This study aims to build upon the work of Slobin \& Talay (1984) and previous studies on other languages by analyzing data from more children.

\section{Data}

Analyzed data are available through Child Language Data Exchange System (CHILDES) at http://childes.psy.cmu.edu/ (Mac Whinney, 1995). The data come from a particular interaction format; most of the time discourse carried out between an adult female researcher and a small child at home. In some cases, parents, care- givers, siblings are also included in the dialogues. The investigator in the dialogues (EXP) was initially a stranger who became more and more familiar with the child (CHI) in the course of several days of psycholinguistic testing and free play. The children all came from professional, college-educated families in Istanbul and Ankara.

There are a total of 36 children in the data, 4 children in each age group. The data was collected at 4 months intervals. There are a total of 43 files in the data grouped as follows: 
Age 2 group: 3 files 2;0+5 files 2;4 5 files 2;8 $=13$

Age 3 group: 5 files $3 ; 0+6$ files $3 ; 4+5$ files $3 ; 8=16$

Age 4 group: 6 files $4 ; 0+6$ files $4 ; 4=12$

\subsection{Data Analysis Method}

Data have been analyzed using CLAN analysis and hand-counting. The transcripts are analyzed for subject type (null, pronoun or lexical NP), verb type (verbal, existential or non-verbal) and clause type (declarative, negative or imperative). Interrogatives were excluded. The subject heads of non-finite clauses and genitive phrases are not within the scope of this study. Sentences where there are two main verbs have been included and calculated as two. Both simple, complex and embedded sentences are included. Cases of a noun followed by an adjective have been scored as nonverbal sentences containing an adjective as the predicate.

\section{Results}

I will demonstrate the use of pro-drop and overt subject by children with actual examples from the data. In the following example, the child is using the overt subject to express contrast (all children's utterances are provided in italic):

(2) EXP: Ben de güzel oyun-lar öğreneyim

I also good game-PL learn-OPT-1SG

'I should learn good games as well'.

CHI: Tabii, ögren.

Of course, learn- 3SG

'Of course, learn'

CHI: Ben de ögren-ir-im. (Ömer, 2;8)

I also learn-AOR-1SG

'I will also learn.'

As can be observed from the next example (3), the subject NP, providing new information, is used as an answer to the question. Note that plural suffix on the verb is redundant as the NP is overt. 
(3) EXP: bu ev-de kim-ler otur-uyor?

This house-LOC who-PL live-PRES-3sg

'Who else is living in this house?'

CHI: abi-ler otur-uyor (Ömer, 2;8)

Brother-PL live-PROG-3sg

'Brothers are living'

It was also observed from the data that in some cases where the adult grammar will prefer pro-drop, such as the context of given information, the child uses the subject:

(4) EXP: Köpek-ler ne yap-ar?

dog-PL what do-AOR

'What do dogs do?'

CHI: on-lar 1sır-1r (Nağme, 3;4)

It-PL bite-AOR-3SG

'They bite'.

When the context is established, it is common to delete subjects in Turkish and this strategy is also employed productively by children as can be seen from example (5)

(5) EXP: Baba-n-1 anlat

Dad- 2SGPOSS-ACC tell-3SG

'Describe your father'

CHI: yalancı birisi (Nağme, 3;0)

Liar someone

'He's a liar'.

EXP: Ne iş yap-ar?

What job do-AOR-3SG

'What does he do?'

CHI: yat-ar (Nağme, 3;0)

Sleep-AOR-3SG

'He sleeps.'

12 
EXP: Her gün gid-er mi?

Every day go- do-AOR-3SG-QUE

'Does he go everyday?'

CHI: gid-er (Nağme, 3;0)

go-AOR-3SG

'He goes.'

Old information does not need to be repeated in answer to the question. Here in the following example (6) is an example of the child's use of pro-drop in existential structure, which shows that he is fully aware of the pragmatics:

(6) EXP: Bu aslan-ın kuyruğ-u var mı?

This lion-GEN tail-POSS there QUE

'Does this lion have a tail?

CHI: Tabii, var (Ömer, 2;8)

Of course, there is

'Of course, he has'.

If two sentences have the same subject then the child tends to use pro-drop and not repeat the subject, as can be observed from (7):

(7) EXP: Karanlık-ta öcü gel-iyor.

Dark-LOC ghost come-PROG

'Ghosts come in the dark'.

CHI: Cam-lar-a vur-uyor (Levent, 3;4)

Glass-PL-DAT knock-PROG-3SG

'A ghost hits the glass'.

However, in some cases children dropped the pronoun, where they should not have. In the following example (8), where the experimenter is asking specifically about the subject, the child fails to provide it.

(8) EXP: O-nu kim al-dı san-a?

that-ACC who buy-PAST you-DAT

'Who bought that for you?' 
CHI: al-dl-lar. (Ömer, 2;8)

Buy-PAST-3PL

'They bought (it)'.

Examples (9) and (10) are other examples for overgeneralization of pro-drop. Again, the experimenter had to ask a question to the child to clarify who the actual subject is.

(9) CHI: Ben-i sev-iyor-lar (Gaye, 4;4)

I-ACC love-PROG-3PL

'They love me'.

EXP: Kim sev-iyor?

Who love-PROG

'Who loves you?'

CHI: birisi, başka-ları (Gaye, 4;4)

Someone-POSS3SG other-PL-POSS

'someone, other people.'

Again in the next example (10) the experimenter raises a question to clarify the agent of the action:

(10) EXP: Bu ev-de kim ütü-lüyor oğlu-m?

This house-LOC who iron-PROG-3SG son-POSS1sg

'Who does the irning in this house my son?'

CHI: ütü-lüyor (Tan, 3;0)

iron-PROG-3SG

'He/she irons'

EXP: Anne-n mi ütü-lüyor?

Mother-POSS QUE iron-PROG-3SG

'Is it your mom who does the ironing?'

14 
CHI: anne-m değil dadı-m ütü-lüyor (Tan, 3;0)

Mother-POSS1SG not nanny-POSSS1SG iron-PROG-3SG

'Not my mom, my nanny irons'.

EXP: Dadı-n mı ütü-lüyor?

nanny-POSS QUE iron-PROG-3SG

'Is it your nanny who does the ironing?'

CHI: $h l$ (Tan, 3;0)

yes

'yes'.

Since the data is in the form of dialogues between the experimenter and the child, the subject pronoun that is used most commonly is the first person singular form 'ben'. This is also consistent with previous results in literature Göksel \&Kerslake (2005:273), where it was reported that first or second person pronoun is used more common in overt subject contexts rather than the third person pronoun.

(11) EXP: Sen resim yap-1yor mu-sun?

You picture do-PROG QUE-2SG

'Do you draw?'

CHI: yap-a-ma-m ben resim (Ömer, 2;8)

Do-ABIL-NEG-1SG I painting

'I can't paint.'

Following is an example where the use of subject is required since new information is being expressed. It should be noted that the child places the subject in post verbal position, since the pragmatics of the sentence requires that the action is more important than stressing the subject. This also shows that children know the pragmatics of the flexible word order in Turkish (Altan , 2006):

(12) EXP: Bardağ-in nerde sen-in?

Glass-POSS 2sg where-LOC you-GEN2SG

'Where is your glass?' 
CHI: götür-dü anne-m (Alper, 2;8)

take-PAST-3SG mother-POSS1SG

'My mom took (it).'

Once the subject is introduced into the discourse, pro-drop is employed by the child:

(13) CHI: tırmala-dı kurt (Vahide, 2;0)

Scratch-PAST-3SG wolf

'The wolf scratched'

CHI: ttrmala-d $d$ (Vahide, $2 ; 0$ )

Scratch-PAST-3SG

'(he) scratched'

CHI: çok tırmala-dı (Vahide, 2;0)

very scratch-PAST-3SG

'(he) scratched a lot'

The data show that children avoid the subject where it can be recovered from the context, which indicates that they are aware of the pragmatic use of the null-subject option. There are only a few cases where they overgeneralize the pro-drop and their utterance causes ambiguity. They use the pro-drop strategy in both verbal and nonverbal sentences (including existential sentences). They also employ the pro-drop with different kinds of verbs passive, reflexive and negative.

Following Wang et al. (1992), the mean percentage of sentences with null-subjects for each speaker was calculated based on the ratios of sentences with null subjects to the total number of subjects produced.

As can be observed from Table 1, although younger children had a few ungrammatical sentences, children from all age groups use pro-drop structures mostly with verbal sentences. Ungrammatical sentences are those where subject is required since it is not recoverable from the context. Those sentences where the experimenter specifically asked for the agent of the action but the child failed to provide it can be given as an example to these. As can be observed, the overall number of ungrammatical sentences is pretty low and also decreases as the age of the group gets bigger. 
Table 1- Distribution of pro-drop sentences

\begin{tabular}{|l|c|c|c|}
\hline \multirow{2}{*}{ Type of sentences } & Age 2 & Age 3 & Age 4 \\
\cline { 2 - 4 } Verbal & 1042 & 1383 & 1207 \\
& $* 7$ & & $* 2$ \\
Non-verbal & 39 & 41 & 66 \\
Existential & 63 & 69 & 49 \\
Imperative & 143 & 55 & 66 \\
TOTAL & 1294 & 1548 & 1390 \\
\hline
\end{tabular}

The following table illustrates the distribution of sentences according to different types of verbs. It should be noted that here verbal sentences with pronoun and verbal sentences with lexical NPs are given as different categories since pronouns are more likely to be omitted. However, lexical NP's have information load and thus are less likely to be deleted. The results from the data from all three age groups are consistent with this theory. The use of the pronouns and lexical NPs signal topic shift and the children demonstrate that they are aware of this pragmatic function. This again supports previous literature where reason provided is that the personal pronoun will often not provide sufficient identification and a more explicit NP is preferred Göksel \&Kerslake (2005).

Table 2- Distribution of sentences with overt subjects

\begin{tabular}{|l|c|c|c|}
\hline \multirow{2}{*}{ Type of sentences } & Age 2 & Age 3 & Age 4 \\
\cline { 2 - 4 } Verbal with pronoun & 103 & 95 & 173 \\
& $* 1$ & $* 1$ & $* 1$ \\
Verbal with lexical NP & 244 & 329 & 482 \\
Non-verbal & 23 & $* 1$ & \\
Existential & 49 & 109 & 59 \\
Imperative & 10 & 4 & 85 \\
TOTAL & 430 & 548 & 14 \\
\hline
\end{tabular}


Table 3- Distribution of pro-drop sentences across ages

\begin{tabular}{|l|c|c|c|}
\hline \multirow{2}{*}{$\begin{array}{l}\text { Pro-drop } \\
\text { Total percentage }\end{array}$} & Age 2 & Age 3 & Age 4 \\
\cline { 2 - 4 } & $75 \%$ & $74 \%$ & $63 \%$ \\
\hline
\end{tabular}

Table 3 suggests that children start language acquisition with over-generalizing the pro-drop strategy and then gradually learn the pragmatic factors. Hence, the use of pro-drop seems to have a small decline as the child gets older. Still, the high percentage of pro-drop use even at the youngest group demonstrate that even around 2;0 children acquiring Turkish know the pragmatic functions and use the pro-drop strategy. The decline in the percentage shows that as they grow older they get better and learn more about the pragmatics of pro-drop and prefer to use overt subjects when necessary.

Figure 1- Distribution of pro-drop sentences

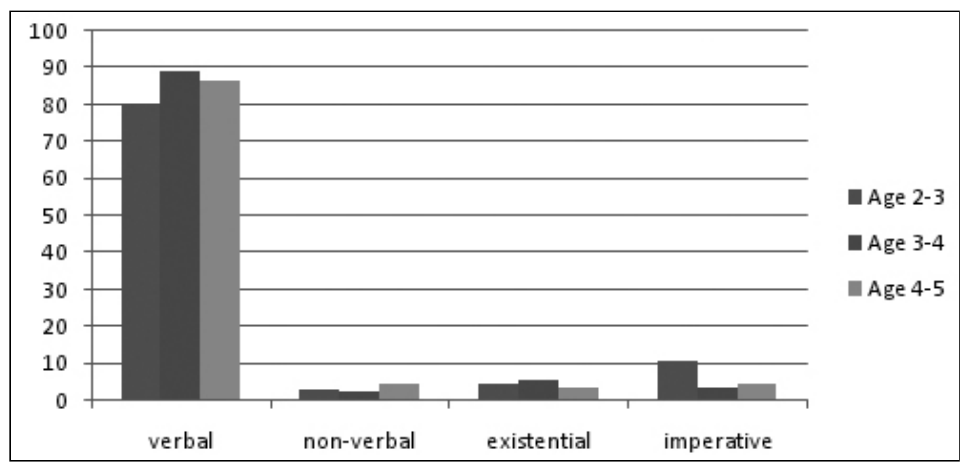

As can be observed from the percentages in Figure 1, children from all three age groups use pro-drop in verbal sentences. The distribution of the use of pro-drop for existential and non-verbal sentences are also similar in all three age groups. As for the imperatives, whereas the children from the youngest group omitted the pronouns children from older groups used more pronouns in comparison.

The next figure displays the distribution of sentences with subjects, again showing the different percentages across ages. 
Figure 2- Distribution of sentences with subjects

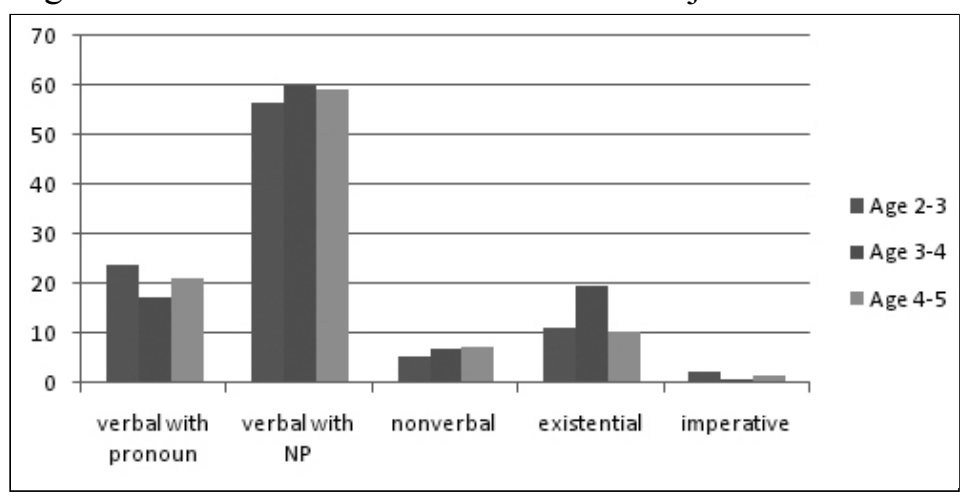

As shown in Figure 2, children use subjects more commonly in verbal sentences. When the type of subject is further analyzed, it is observed that full lexical NPs are more common than pronouns as subjects. The reason behind this is the pragmatic function of lexical NPs as discussed before, since lexical NPs are more likely to provide new information they are overtly used.

Child directed speech in the data has also been analyzed and it is observed that adults speaking with children use null subjects. However, it is difficult to analyze accurate percentages since in the data examined the investigator used similar structures with each child in order to encourage them to speak.

\section{Conclusion}

This study shows that Turkish children treat null subjects as part of their grammar starting from early language acquisition. It was suggested by Zimmer (1984) that subject pronouns in Turkish have contrastive emphasis, they involve the contradiction of an assertion and they serve as indicators of the introductions of new topics. This claim is verified by the use of overt subjects in the data by children, who used them for these same pragmatic functions. These results also support Valian (1991) on Italian children's null subjects: Italian children used subjects in 30\% of their utterances and this data shows that Turkish children used overt subjects $28.6 \%$ on average (among three age groups).

These results are also consistent with the findings of Hyams (1996) where she suggests that children begin their language acquisition with a pro-drop language with optional subjects and then they set their parameters in accordance with the language they experience. Hyams (1996) suggested that restructuring of the Null Subject Parameter takes place around 26 to 28 months. The data here is consistent with this 
in that younger children made more overgeneralization errors where they omitted the subject in a context it was required.

This study suggests that Turkish children prefer to use pro-drop structures. They use pro-drop structures more commonly with verbal predicates. The overt subject is used mostly in existential sentences, where the pragmatics and context actually requires the subject. If they use subject they prefer lexical NPs to pronouns, again consistent with pragmatic factors. This data confirms that pronominal subjects are deleted more often than lexical subjects. If children use a pronoun, they use either first or second person rather than the third person pronoun, which is supporting the findings of Göksel \&Kerslake (2005:273).

Turkish children start their language acquisition with pro-drop, and then learn to use when to use the overt pronoun. This explains why the percentage of pro-drop structures decreases as children get older. They basically correct their overgeneralizations of pro-drop and learn to use the overt subject when the pragmatics require it. These findings support Slobin \&Talay (1984) and Altan (2006) that children acquiring Turkish know the information structure and pragmatics by age 2;0.

\section{Abbreviations}

3PL : third person plural

NEG : negative

ACC : accusative

OPT : optative

AOR : aorist tense

PL : plural

DAT : dative

POSS : possessive

DEF PAST : definite past tense

PROG : progressive tense

GEN : genitive

QUE : question

LOC : locative

\section{References}

Altan, A. 2008. Türkçe'de Sözcük Diziminin Edinimi. In 20nci Ulusal Dilbilim Kurultayı Bildirileri. y. Çotuksöken \& N. Yalçın (eds.) Maltepe Üniversitesi Yayınları, İstanbul, Turkey. 51-63.

Blom, E. and van Geert, P. 2004. Signs of developing grammar: subject drop and inflection in early child Dutch. Linguistics. Vol. 42. Mouton de Gruyter.

Bloom, L. 1970. Language development: form and function in emerging grammars. Cambridge, MA: M. I. T. Press.

Bloom, P. 1990. Subjectless sentences in child language. Linguistic Inquiry 21, 491-504. 
Chomsky, N. 1981. Lectures on Government and Binding. Dordrecht, The Netherlands: Foris.

Clahsen, H. 1991. Constraints on parameter setting. A grammatical analysis of some acquisition stages in German child language, Language Acquisition 1, 361-391.

Enç, M. 1986. Topic switching and pronominal subjects in Turkish, Studies in Turkish Linguistics, D. I. Slobin \& K. Zimmer (eds.). Amsterdam, Philadelphia, John Benjamins.

Erguvanl1, E. 1984.The Function of Word Order in Turkish Grammar. California: University of California Press.

Gerken, L. A. 1991. The metrical basis for children's subjectless sentences. Journal of Memory and Language, 30. 431-451.

Göksel, A. and C. Kerslake 2005 [third reprint 2010]. Turkish, A Comprehensive Grammar. London: Routledge.

Grinstead, J. 2004. Subjects and interface delay in child Spanish and Catalan. Language. Vol, 80. Linguistic Society of America.

Hyams, N. 1986. Language Acquisition and The Theory of Parameters. Dordrecht, The Netherlands: Reidel.

Hyams, N. 1992. A reanalysis of null subjects in child language. J. Weissenborn, H.

Hyams, N. and Wexler, K. 1993. On the grammatcal basis of null subjects in child language in Linguistic Inquiry, 24. 421-459.

Kim, Y. 1996. The acquisition of Korean. In D. Slobin (ed.). The Crosslinguistic Study of Language Acquisition, Vol. 4. Hillsdale, NJ: Erlbaum.

Kornfilt, Jaklin. 1984. Case marking, agreement, and empty categories in Turkish. Doctoral dissertation, Harvard University.

Lillo-Martin, D. 1986. Effects of the Acquisition of Morphology on Syntactic Parameter Setting. In S. Berman, J.-W. Choe, \& J. McDonough (Eds.), Proceedings of NELS 16, 305-321. Amherst: GLSA.

Lillo-Martin, D. 1986. Effects of the Acquisition of Morphology on Syntactic Parameter Setting. In S. Berman, J.-W. Choe, \& J. McDonough (Eds.), Proceedings of NELS 16, 305-321. Amherst: GLSA.

Lillo-Martin, D. 1991. Universal Grammar and American Sign Language: Setting the Null Argument Parameters.Dordrecht: Kluwer Academic Publishers.

Lillo-Martin, D. 1994. Setting the null argument parameters: Evidence from American Sign Language and other languages. In B. Lust, G. Hermon, J.Kornfilt (eds.), In Sytanctic Theory and First Language Acquisition- Crosslinguistics Perspectives: Binding, Dependencies and Learnability, 301-318. Hillsdale, NJ: Erlbaum.

MacWhinney, B. 1995. The CHILDES project: Tools for Analyzing Talk. Hillsdale, NJ: Lawrance Erlbaum Associates. 
Mazuka, R., Lust, B. Wakayama, T \& Snyder, W. 1986. Distinguishing effects of parameters in early syntax acquisition: A cross- linguistic study of Japanese and English in Papers and Reports on Child Language Development, 25, 73-82.

Özsoy, S. 1987. Null subject parameter and Turkish, Studies on Modern Turkish, H. E. Boeschoten \& L. Th. Verhoeven (eds). Proceedings of the Third Conference on Turkish Linguistics, Tilburg University Press.

Öztürk, B. 1999. Turkish as a non-pro-drop language. MA Thesis, Boğaziçi University, Istanbul.

Öztürk, B. 2000. Bir Adıl-Düşürme dili olarak Türkçe. XIII. Türk Dilbilim Kurultayı Bildirileri, (Proceedings of the XIII. National Conference on Turkish Linguistics, Boğaziçi University, Istanbul.

Pierce, A. 1992 Language Acquisition and Syntactic Theory: A Comparative Analysis of French and English Child Grammars. Dordrecht, Kluwer.

Slobin, D. I. 1982. Universal and particular in the acquisition of language. In Language Acquisition: The State of Art. Wanner, E. \& Gleitman, L. (eds.). Cambridge: Cambridge University Press.

Slobin, D. I \& Talay, A. 1986. Development of Pragmatic Uses of Subject Pronouns in Turkish child language. In A. Aksu-Koç \& Erguvanlı Taylan (eds.). Proceedings of the Turkish Linguistics Conference. Pp 207-228. Istanbul: Boğaziçi University Press.

Taylan, E. E. 1986. Pronominal vs. Zero Representation of Anaphora in Turkish. In Studies in Turkish Linguistics, (eds.) Dan I. Slobin \& Karl Zimmer, Amsterdam: John Benjamins,206-233.

Valian, V. 1991. Syntactic subjects in the early speech of American and Italian children.Cognition 40, 21-81.

Valian, V. \& Aubry, S. 2005. When opportunity knocks twice: two-year-olds' repetition of sentence subjects. Journal of Child Language 32, 617-641.

Valian, V. \& Eisenberg, Z. 1996. Syntactic subjects in the speech of Portuguese-speaking children. Journal of Child Language 23, 103-128.

Wang, Q., Lillo- Martin, D., Best, C. T., Levitt, A. 1992. Null subjects vs. Null object: some evidence from the acquisition of Chinese and English. Language Acquisition, 2. 221-254.

Weissenborn, J. 1992. Null Subjects in Early Grammars: Implications for Parameter Setting Theories, in J. Weissenborn, H. Goodluck and T. Roeper, eds., Theoretical Issues in Language Acquisition, Hillsdale, NJ, Lawrence Erlbaum.

Zimmer, K. 1984. On the sytnactic properties of empty categories. In Türk Dilbilimi Konferansı Bildirileri. 9-10 Ağustos 1984. Aksu-Koç, A. \& Erguvanl1-Taylan, E. (eds.) Boğaziçi University. 